\title{
Cytological screening for cervical cancer in women of reproductive age group
}

\author{
Swati Mittal*, Anagha J. Kamath
}

Department of Obstetrics and Gynecology, Kasturba Medical College, Mangalore, Karnataka, India

Received: 25 September 2017

Accepted: 30 October 2017

\section{*Correspondence:}

Dr. Swati Mittal,

E-mail: swati0611@gmail.com

Copyright: (C) the author(s), publisher and licensee Medip Academy. This is an open-access article distributed under the terms of the Creative Commons Attribution Non-Commercial License, which permits unrestricted non-commercial use, distribution, and reproduction in any medium, provided the original work is properly cited.

\begin{abstract}
Background: Cervical cancer is a malignant neoplasm arising from cells of cervix uteri. It is the second most common cancer among women worldwide, affecting about 16 per 1,00,000 women each year.

Methods: A cross sectional study of 400 women of reproductive age group (21-49 years) attending Lady Goschen Hospital and KMC Hospital, Attavar, Mangalore was conducted, and women were screened for the presence of cervical cancer by Pap smear. The results were analyzed with respect to age distribution, age at marriage, parity, symptoms and per-speculum findings. Pregnant women and women with active infection of the genital tract were excluded from the study population.

Results: The age range was 21 to 49 years. Mean age was 38.14 years. Of the 400 women, 398 were married and majority of these, $237(59.5 \%)$, got married between 21-25 years. Menstrual irregularity was the most common presenting symptom, 150/400 (37.5\%). Abnormal per speculum findings were seen in 102/400 (25.5\%). 17 of 400 Pap smears were abnormal, of which $1(0.25 \%)$ was AG-FN, 2 ASCUS (0.5\%), $3(0.75 \%)$ ASC-H, $1(0.25 \%)$ LSIL, 7 $(1.75 \%)$ HSIL and $3(0.75 \%)$ SCC. Mean age for cancer cervix patients was 42.33 years.

Conclusions: Pap smear screening, which appears to be the most feasible and affordable mode for control of carcinoma cervix in developing countries like India, should be carried out in all women of reproductive age group.
\end{abstract}

Keywords: Carcinoma cervix, CIN (cervical intraepithelial neoplasia), HPV (human papilloma virus)

\section{INTRODUCTION}

Cervical cancer is a malignant neoplasm arising from the cervix uteri. It is the most common cancer in developing countries and the sixth most common in developed countries. In India cervical cancer is the second most common cancer among women. ${ }^{1}$ It affects about 16 per $1,00,000$ women each year and kills about 9 per $1,00,000$ per year. ${ }^{2}$

The early stages of cervical cancer can be completely asymptomatic. One of the most common symptoms of cervical cancer is abnormal vaginal bleeding (menorrhagia, dysmenorrhea), but in some cases, there may be no obvious symptom until the cancer has progressed to an advanced stage.

The other common symptoms include vaginal discharge, dyspareunia, and low backache. ${ }^{3}$ The main risk factor for cervical cancer is infection with human papilloma virus (HPV) types 16, 18, 31, 33, 35, 42, 55, 58. HPV types 16 and 18 are the cause of $70 \%$ of cervical cancer worldwide while 31 and 45 are the cause of another $10 \% .{ }^{4}$ Women who have many sexual partners are at a higher risk. The use oral contraceptive pills and smoking have also shown to increase the risk. Cancer risk has also been shown to be higher among women in lower socio-economic groups and in those with lower levels of education. ${ }^{5}$ 
There are two main types of cervical cancer: Squamous cell carcinoma (SCC) and Adenocarcinoma. SCC is the more common type of cancer, accounting for about three quarter of all the cases. ${ }^{6}$ Invasive disease arises as a consequence of progression from mild dysplasia through severe dysplasia to carcinoma in situ. These precursor lesions are also known as Cervical Intraepithelial Neoplasia (CIN), and represent various degrees of disordered cell maturation in cervical epithelium. ${ }^{7,8}$

Various methods for screening cervical cancer include Papanicolaou smear (cytological smear), visual inspection method using acetic acid (VIA) and Lugol's iodine (VILI), and HPV DNA testing. However, it is well established that the best method for early detection of precancerous lesions of the cervix is cytological examination by Pap smear. The mortality related to cervical cancer can be substantially reduced through early detection and treatment. Therefore, cytological evaluation still plays an important role for early detection of dysplasia or pre-invasive cervical carcinomas.

\section{METHODS}

The present study aimed at screening 400 women of reproductive age group (21-49 years), attending the outpatient department, as well as those admitted in Lady Goschen Hospital and KMC Hospital, Attavar, by the means of conventional Pap smears. The study period was 1 and 1/2 years from October 2013 to March 2015. These smears were graded according to "The Bethesda system" (2001). The results of the cytological smears were analyzed with respect to age distribution; age at marriage; parity; symptoms and per speculum findings. These results were analyzed statistically (descriptive study by proportions using chi square test). The results of the present study were also compared with the previous studies.

\section{PAP smears- “The (2001) Bethesda System"}

In 1988, the National Cancer Institute workshop was held in Bethesda, Maryland, resulted in development of The Bethesda System for cytologic reporting of smears. After numerous workshops and discussions, in the year 2001, the redefined terminologies for female genital tract cytology includes:

\section{Specimen type}

Conventional smear versus liquid based cytology smear versus other.

\section{Statement on specimen adequacy}

- Satisfactory of evaluation

- Satisfactory for evaluation but limited by (specify reason)

- Unsatisfactory (specify reason)
(Reasons for satisfactory but limited /Unsatisfactory smears include scanty cellularity, poor fixation /preservation, presence of foreign material (ex: Lubricant), partially /completely obscured by inflammation, partially /completely obscured by blood, no endocervical component and insufficient patient history. In these cases, a repeat pap smear is advised.)

\section{General categorization/ interpretation/ result}

NILM (Negative for intraepithelial lesion or malignancy) which includes

- Organisms like Trichomonas, Actinomyces, Candida, Shift in flora (Bacterial Vaginosis), Herpes Simplex related changes)

- Reactive cellular changes due to inflammation, radiation, and intrauterine devices.

- Atrophy.

\section{Epithelial cell abnormalities}

\section{Squamous cells}

- Atypical squamous cells: of undetermined significance (ASCUS), cannot exclude HSIL (ASCH)

- Low-grade squamous intraepithelial lesion (LSIL) encompassing cellular changes consistent with HPV infection, Mild dysplasia/ Cervical intraepithelial neoplasia - I (CIN I)

- High-grade squamous intraepithelial lesion (HSIL) encompassing moderate dysplasia/ Cervical intraepithelial neoplasia-II (CIN-II), severe dysplasia/ Cervical intraepithelial neoplasia-III (CINIII)/ Carcinoma-in-situ (CIS)

- Squamous cell carcinoma (SCC)

Glandular cells

- Atypical: endocervical cells (not otherwise specified), endometrial cells (not otherwise specified), glandular cells (not otherwise specified)

- Atypical cells favouring neoplasia: endocervical cells favouring neoplasia, glandular cells favouring neoplasia

- Endocervical adenocarcinoma in situ

- Adenocarcinoma: Endocervical, Endometrial, Extrauterine, not otherwise specified.

\section{RESULTS}

The age range of women included in the study was between 21 to 49 years. Maximum number of women, i.e., $173(43.2 \%)$ was in the age group $41-49$ years and the lowest was in the age group 21-30 years i.e. 84 $(21 \%)$. Mean age of study population was 38.14 years. $398(99.5 \%)$ women in the study group were married and $2(0.5 \%)$ were unmarried but sexually active. 287 (71.8\%) women had parity of 1-2. 


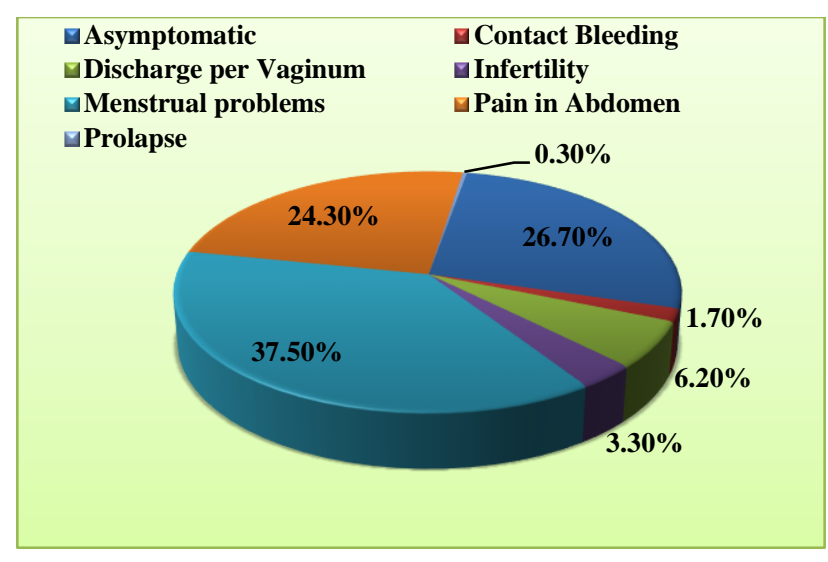

Figure 1: Symptoms $(n=400)$.

The symptoms with which they presented included contact bleeding, vaginal discharge, infertility, menstrual problems, abdominal pain and utero-vaginal prolapse. However, maximum women, i.e. 150 (37.5\%) presented with menstrual problems (Figure 1). On per speculum examination, in $102(25.5 \%)$, abnormalities like erosion on cervix, nabothian cyst and utero-vaginal prolapse were detected. Out of the total 400 women included in study population, on Pap smear examination, 111/400 women had abnormal pap smears of which majority, 57 (14.25\%) smears, were inflammatory, $12(3.0 \%)$ were atrophic, 9 (2.25\%) had bacterial vaginosis, $15(3.75 \%)$ had candida infection, $1(0.25 \%)$ had trichomonas vaginalis, 1 $(0.25 \%)$ had AG-FN, 2 were ASCUS $(0.5 \%), 3(0.75 \%)$ were ASC-H, $1(0.25 \%)$ was LSIL, 7 (1.75\%) HSIL and $3(0.75 \%)$ were SCC (Figure 2$)$.

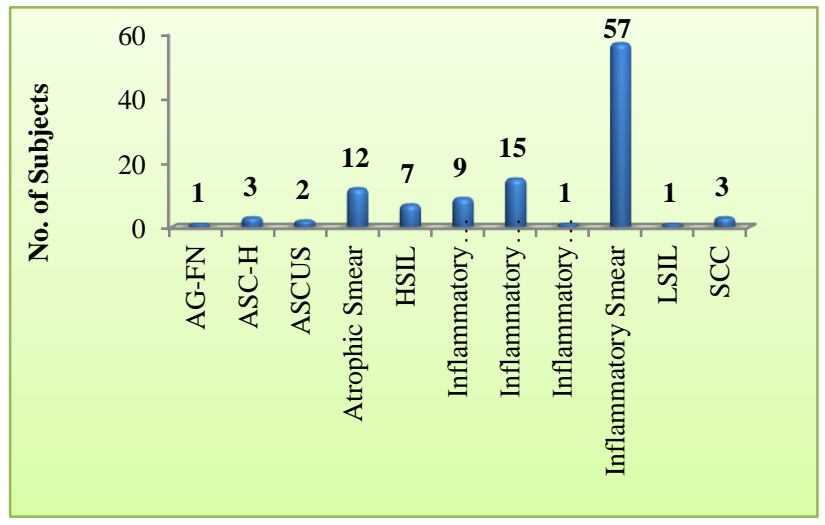

Figure 2: Abnormal PAP smear reports $(n=111)$.

The mean age for cancer patiets with cancer cervix was 42.33 years and all these women were married and had parity between 2-3.

Table 1: Age groups and abnormal pap smear reports $(\mathbf{n}=111)$.

\begin{tabular}{|c|c|c|c|c|c|c|}
\hline \multirow{3}{*}{ PAP smear report } & \multicolumn{6}{|c|}{ Age Group (in years) } \\
\hline & \multicolumn{2}{|c|}{ 21-30 } & \multicolumn{2}{|l|}{$31-40$} & \multicolumn{2}{|l|}{ 41-49 } \\
\hline & No. of subjects & $\%$ & No. of subjects & $\%$ & No. of subjects & $\%$ \\
\hline AG-FN & 0 & 0 & 0 & 0 & 1 & 1.9 \\
\hline ASC-H & 0 & 0 & 3 & 7.5 & 0 & 0 \\
\hline ASCUS & 0 & 0 & 1 & 2.5 & 1 & 1.9 \\
\hline Atrophic Smear & 0 & 0 & 1 & 2.5 & 11 & 20.8 \\
\hline HSIL & 0 & 0 & 1 & 2.5 & 6 & 11.3 \\
\hline Inflammatory smear & 13 & 72.2 & 23 & 57.5 & 21 & 39.6 \\
\hline Inflammatory smear Bacterial vaginosis & 0 & 0 & 4 & 10.0 & 5 & 9.4 \\
\hline Inflammatory smear Candida vaginalis & 5 & 27.8 & 5 & 12.5 & 5 & 9.4 \\
\hline Inflammatory smear Tricho vaginalis & 0 & 0 & 1 & 2.5 & 0 & 0 \\
\hline LSIL & 0 & 0 & 0 & 0 & 1 & 1.9 \\
\hline SCC & 0 & 0 & 1 & 2.5 & 2 & 3.8 \\
\hline Total & 18 & 100 & 40 & 100 & 53 & 100 \\
\hline
\end{tabular}

p value- 0.019

The association between age groups and abnormal Pap smear results (Table 1) was found to be statistically significant ( $\mathrm{p}$ value 0.019 ) and the association between parity and abnormal Pap smear results was also found to be statistically significant (Table 2 - p value 0.034 ).

The maximum numbers of pre-malignant lesions were seen women in the age group of 40-49 years. This signifies that effective screening should be done in this age group to prevent carcinoma cervix. A single Pap smear done at this age can prevent carcinoma in significant number of cases.

\section{DISCUSSION}

In the present study, out of 400 patients who were subjected to Pap smear examination, $111(27.75 \%)$ had abnormal Pap smear report. Among these 18 (4.5\%) were between 21-30 years, $40(10 \%)$ were between 31-40 years, and $53(13.25 \%)$ were between $41-49$ years. 
Table 2: Parity and abnormal pap smear reports $(n=111)$.

\begin{tabular}{|c|c|c|c|c|c|c|}
\hline \multirow{3}{*}{ PAP Smear Report } & \multicolumn{6}{|l|}{ Parity } \\
\hline & \multicolumn{2}{|l|}{ None } & \multicolumn{2}{|l|}{$1-2$} & \multicolumn{2}{|l|}{ More than 2} \\
\hline & No. of Subjects & $\%$ & No. of subjects & $\%$ & No. of subjects & $\%$ \\
\hline AG-FN & 0 & 0 & 0 & 0 & 1 & 3.3 \\
\hline ASC-H & 0 & 0 & 2 & 2.7 & 1 & 3.3 \\
\hline ASCUS & 0 & 0 & 1 & 1.4 & 1 & 3.3 \\
\hline Atrophic Smear & 1 & 12.5 & 9 & 12.3 & 2 & 6.7 \\
\hline HSIL & 0 & 0 & 1 & 1.4 & 6 & 20.0 \\
\hline Inflammatory smear & 3 & 37.5 & 40 & 54.8 & 14 & 46.7 \\
\hline Inflammatory smear Bacterial Vaginosis & 0 & 0 & 8 & 11.0 & 1 & 3.3 \\
\hline Inflammatory smear Candida Vaginalis & 4 & 50 & 9 & 12.3 & 2 & 6.7 \\
\hline Inflammatory smear Tricho Vaginalis & 0 & $0 \%$ & 1 & 1.4 & 0 & 0 \\
\hline LSIL & 0 & 0 & 1 & 1.4 & 0 & 0 \\
\hline $\mathrm{SCC}$ & 0 & 0 & 1 & 1.4 & 2 & 6.7 \\
\hline Total & 8 & 100 & 73 & 100 & 30 & 100 \\
\hline
\end{tabular}

$\mathrm{p}$ value- 0.034

Among these 3 had squamous cell carcinoma (SCC) of cervix. The mean age of these three cancer cervix cases was 42.33 years, which was similar to that, reported in previous studies. ${ }^{9-13}$

The incidence of carcinoma cervix in the present study was found to be $0.75 \%$ which was found to be in concordance with previous studies. ${ }^{13-18}$

In the present study $100 \%$ of the women having cancer cervix were married. In studies done previously, $86.5 \%$ to $88.4 \%$ women were married which was similar to our study. ${ }^{11,12}$ This high percentage of married women amongst women diagnosed with cervical cancer (in the study population) could be attributed to early age at marriage and high parity, which are also individual risk factors for cancer cervix.

Out of the 400 women in study group, $43(10.75 \%)$ were nulliparous, $287(71.75 \%)$ had parity of $1-2$ and 70 $(17.5 \%)$ had parity more than 2. Among the 111 abnormal smears, 8 (2\%) were nulliparous, 73 (18.25\%) had parity of $1-2$ and $30(7.5 \%)$ had parity of more than 2. Among the 3 cases of cancer cervix, 1 had parity between 1-2 and 2 had parity more than 2 . The mean parity for cancer cervix in the present study is 2 to 3 which was similar to previous studies. ${ }^{13,15,17}$ Increasing parity as a risk factor for cancer cervix has been stated traditionally and the present study also shows a similar result.

\section{CONCLUSION}

Even though cervical cancer is the second leading site of cancer among women; women in the community are ignorant about the risks, risk factors and symptoms of this particular cancer. Specific knowledge on cervical cancer is therefore a critical element in determining whether a woman will undergo Pap test or not. Based on the analyzed data, it is felt that Pap smear screening, which appears to be the most feasible and affordable mode for control of carcinoma cervix in developing countries like India, should be carried out in all women of reproductive age group. A single Pap smear done in reproductive age can prevent carcinoma in significant number of cases. However, conventional Pap smears alone cannot pick up all the epithelial abnormalities and simultaneous HPV DNA testing will complement the detection of cervical cancer.

\section{ACKNOWLEDGMENTS}

Authors would like to thank Dr. Anagha J. Kamath for the support during study.

\section{Funding: No funding sources Conflict of interest: None declared Ethical approval: Not required}

\section{REFERENCES}

1. Armstrong EP. Prophylaxis of cervical cancer and related cervical disease: a review of the costeffectiveness of vaccination against oncogenic HPV types. J Managed Care Pharmacy. 2010 Apr;16(3):217-30.

2. Ferlay J. GLOBOCAN 2002: cancer incidence, mortality and prevalence worldwide, version 2.0, Lyon, France: International Agency for Research on Cancer, 2004.

3. Kumar V, Abbas AK, Fausto N, Mitchell RN. Robbins Basic Pathology. $8^{\text {th }}$ ed. Saunders Elsevier;2007:718-721.

4. Dillman. edited by Oldham RK, Robert O. Principles of cancer biotherapy. $5^{\text {th }}$ ed. Dordrecht: Springer;2009:149.

5. Walboomers JM, Jacobs MV, Manos MM, Bosch FX, Kummer JA, Shah KV et al. Human papillomavirus is a necessary cause of invasive 
cervical cancer worldwide. J. Pathol. 1999;189(1):12-9.

6. Vizcaino AP, Moreno V, Bosch FX, MUNoz N, Barros- Dios XM, Borras J et al. International trends in incidence of cervical cancer: II. Squamous- cell carcinoma. Int J Cancer. 2000 May 1;86(3):429-35.

7. Narod SA, Thompson DW, Jain M, Wall C, Green LM, Miller AB. Dysplasia and the natural history of cervical cancer: early results of the Toronto Cohort Study. Eur J Cancer. 1991;27:1411-6.

8. Holowaty P, Miller AB, Rohan T, To T. Natural history of dysplasia of the uterine cervix. J Natl Cancer Inst. 1999;91:252-8.

9. Boyd JT, Doll R. (1964). A study of the aetiology of carcinoma of the cervix uteri. $\mathrm{Br} \mathrm{J}$ Cancer. 1964;18(3):419.

10. Badar F, Anwar N, Meerza F, Sultan F. Cervical carcinoma in a Muslim community. Asian Pacific J Cancer Prevent. 2007;8(1):24.

11. Bhurgri Y, Nazir K, Shaheen Y, Usman A, Faridi N, Bhurgri $\mathrm{H}$ et al. Patho-epidemiology of cancer cervix in Karachi South. Asian Pacific J Cancer Prevent. 2007 Jul 1;8(3):357.

12. Aswathy S, Quereshi MA, Kurian B, Leelamoni K. Cervical cancer screening: Current knowledge and practice among women in a rural population of Kerala, India. Indian J Med Res. 2012;136(2):205.

13. Mhaske MS, Jawadekar SJ, Saundale SG, Lakde RN. Study of association of gynaecological morbidities and cervical dysplasia among rural women. Global J Res Anal. 2013;2(2):173-5.

14. Macgregor JE, Baird D. (1963). Detection of cervical carcinoma in the general population. BMJ. 1963;1(5346):1631.

15. Wahi PN, Luthra UK, Mali S, Shimkin MB. Prevalence and distribution of cancer of the uterine cervix in Agra District, India. Cancer, 1972;30(3):720-5.

16. Wasti S, Ahmed W, Jafri A, Khan B, Sohail R, Hassan S. Analysis of cervical smears in a Muslim population. Annal Saudi Med. 2004;24:189-192.

17. Misra JS, Srivastava S, Singh U, Srivastava AN. Risk-factors and strategies for control of carcinoma cervix in India: Hospital based cytological screening experience of 35 years. Indian $\mathrm{J}$ Cancer. 2009;46(2):155.

18. Mulay K, Swain M, Patra S, Gowrishankar S. A comparative study of cervical smears in an urban Hospital in India and a population-based screening program in Mauritius. Indian $\mathrm{J}$ Pathol Microbiol. 2009;52(1):34.

Cite this article as: Mittal S, Kamath AJ.

Cytological screening for cervical cancer in women of reproductive age group. Int J Reprod Contracept Obstet Gynecol 2017;6:5464-8. 